\title{
Amphotericin B and Other Polyenes-Discovery, Clinical Use, Mode of Action and Drug Resistance
}

\author{
Hans Carolus ${ }^{1,2,+} \mathbb{D}$, Siebe Pierson ${ }^{1,2,+}$, Katrien Lagrou ${ }^{3,4}(\mathbb{D}$ and Patrick Van Dijck $1,2, * \mathbb{D}$ \\ 1 VIB-KU Leuven Center for Microbiology, 3001 Leuven, Belgium; hans.carolus@kuleuven.be (H.C.); \\ siebe.pierson@kuleuven.be (S.P.) \\ 2 Laboratory of Molecular Cell Biology, Department of Biology, KU Leuven, 3001 Leuven, Belgium \\ 3 Laboratory of Clinical Bacteriology and Mycology, Department of Microbiology, Immunology and \\ Transplantation, KU Leuven, 3001 Leuven, Belgium; katrien.lagrou@uzleuven.be \\ 4 Department of Laboratory Medicine and National Reference Center for Mycosis, UZ Leuven, \\ 3001 Leuven, Belgium \\ * Correspondence: patrick.vandijck@kuleuven.vib.be; Tel.: +32-1632-1512 \\ + These authors contributed equally to this work.
}

Received: 30 October 2020; Accepted: 25 November 2020; Published: 27 November 2020

\begin{abstract}
Although polyenes were the first broad spectrum antifungal drugs on the market, after 70 years they are still the gold standard to treat a variety of fungal infections. Polyenes such as amphotericin B have a controversial image. They are the antifungal drug class with the broadest spectrum, resistance development is still relatively rare and fungicidal properties are extensive. Yet, they come with a significant host toxicity that limits their use. Relatively recently, the mode of action of polyenes has been revised, new mechanisms of drug resistance were discovered and emergent polyene resistant species such as Candida auris entered the picture. This review provides a short description of the history and clinical use of polyenes, and focusses on the ongoing debate concerning their mode of action, the diversity of resistance mechanisms discovered to date and the most recent trends in polyene resistance development.
\end{abstract}

Keywords: amphotericin B; polyene; antifungal drug resistance; mode of action; discovery

\section{History of Polyenes as Antifungal Drugs}

Polyenes were, after griseofulvin [1], the first fungal-specific antibiotics on the market and ever since, more than 200 polyene antifungals have been discovered [2], of which amphotericin B, nystatin and natamycin (Figure 1) are most commonly used in antifungal therapy [3]. In 1949, microbiologist Elizabeth L. Hazen and chemist Rachel F. Brown isolated the first antifungal polyene-fungicidin-later called nystatin after New York State, where the meeting of the National Academy of Sciences in which fungicidin was presented, took place that year [4-6]. Nystatin was purified as a fermentation product of Streptomyces noursei, cultured from a soil sample of the farm of W. Nourses, after which the antibiotic producing actinomycete species was named [6]. Nystatin was patented by the E.R. Squibb and Sons Institute and became one of the first antimycotic drugs on the market. Early on, it became apparent, however, that nystatin had poor gastrointestinal absorption and could thus only be used to treat topical mycoses [7]. Therefore, the same research group continued their broad screening of soil-cultivated fermentation broths and in January 1953, a fermentation broth from the Streptomyces nodosus culture M4575, cultured from a soil sample of the Orinoco basin in Venezuela, showed remarkable antifungal activity [5,7]. Two active compounds were isolated: amphotericin A and amphotericin B (AmB), named after their amphoteric properties. These polyenes were chemically similar to nystatin, but the ultraviolet absorption spectrum showed additional maxima at longer wavelengths [7]. After successful 
purification, the tetraene amphotericin A showed an antifungal spectrum similar to nystatin, while the heptaene AmB had a significantly greater antifungal activity compared to nystatin and amphotericin A [7]. It took over one and a half decades to completely unravel the chemical structure of AmB [8]. AmB is, like other polyenes, a complex macrolide antibiotic, characterized by an almost flat macrolactone ring (hence the name macrolide) with a series of conjugated double bonds (Figure 1) [9]. The latter discriminates polyenes from antibacterial macrolides such as erythromycin [9]. Depending on the number of conjugated double bonds, polyenes can be classified into trienes, tetraenes, pentaenes, hexaenes, heptaenes, etc. [9,10]. In general, polyenes consist of a hydrophobic polyene "tail" and a hydrophilic "head" with a mycosamine group and a polyol chain that holds a number of hydroxyl groups [2].

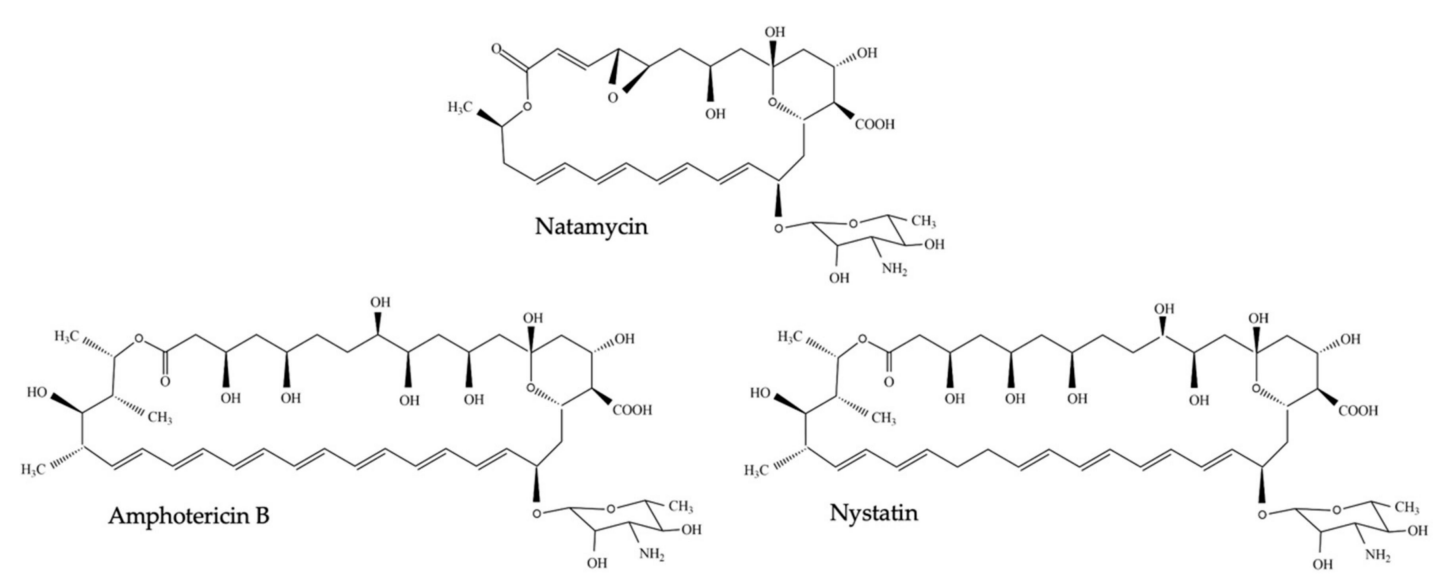

Figure 1. Chemical structure of nystatin, amphotericin B and natamycin (pimaricin).

Due to its amphipathic character, AmB is poorly water soluble and although initially oral treatment of infected mice seemed successful [7], no such effect was obtained in humans [6,7]. Eventually, researchers at the E.R. Squibb and Sons institute used a formulation in which AmB and sodium deoxycholate formed a micellar suspension when reconstituted in a glucose solution $[6,7]$. This preparation, named Fungizone ${ }^{\circledR}$ and commonly referred to as AmB deoxycholate, could yield high blood concentrations of $\mathrm{AmB}$ upon intravenous administration and was very effective against systemic cryptococcosis, histoplasmosis and other deep mucosal infections [7]. Ever since the discovery of $\mathrm{AmB}$, multiple different derivates and formulations have been developed. The latter to counteract the dose-limiting toxicities of $\mathrm{AmB}$, which comprise nephrotoxicity and infusion-related complications (discussed in Section 2. Clinical Use) [11]. Nevertheless, AmB can still be regarded as one of the most fungicidal drugs on the market with a broad spectrum and limited incidence of resistance development (discussed in Section 4. Polyene Resistance), largely due to their mode of action (discussed in Section 3. Mode of Action) [2]. Today, polyenes are still regularly used beyond antifungal treatment, such as the AmB treatment of visceral leishmaniasis [12].

\section{Strengths and Drawbacks of Polyene Use in the Clinic}

Clinical use of AmB and other polyenes has extensively been reviewed elsewhere [2,11,13-15]; here, we only provide a short summary on the most common applications and drawbacks of the use of polyenes as antifungal drugs. About six polyene antifungals have been used for antifungal therapy: AmB, nystatin, natamycin (also called pimaricin), candicidin, trichomycin and methyl partricin [2]. However, only three polyenes remain in widespread therapeutic use today: AmB for systemic mycoses, nystatin for mucosal infections such as oral or vulvovaginal candidiasis and natamycin for ophthalmic infection $[2,3,13]$. Polyenes are still in use because of their broad spectrum of activity (cf. echinocandins, 1st and 2nd generation azoles) against pathogenic yeasts and molds, including Candida spp., Aspergillus spp., Cryptococcus spp., Fusarium spp., Mucorales (e.g., Rhizopus spp.) and 
endemic mycosis (e.g., Histoplasma spp.) [13]. Nevertheless, several studies show that AmB treatment of systemic mycoses caused by species such as Aspergillus terreus [16], Scedosporium spp. [17] and Candida auris [18] might not always be successful, often due to intrinsic or acquired resistance [14]. Still, polyene resistance is rarer $[13,19,20]$, and the relative decrease in susceptibility is smaller, compared to resistance to other drug antifungal classes such as azoles or echinocandins [21,22] (see Section 4. Polyene Resistance). Nevertheless, due to its toxicity and the availability of the (tri)azole and echinocandin antifungals, the use of AmB to treat the most common systemic mycoses such as candidiasis and aspergillosis has decreased [13]. According to the Infectious Diseases Society of America (IDSA) [23] and European Confederation of Medical Mycology [24] (ECMM) guidelines, AmB is still recommended as first line treatment for severe cryptococcosis (often in combination with flucytosine), disseminated histoplasmosis and mucormycosis, while it remains an alternative for other infections upon intolerance, limited availability or failure of other treatments [13,23]. Furthermore, AmB has been recommended as a prophylaxis for invasive Candida [23] and Aspergillus [25] infections in solid-organ transplant recipients and patients receiving immunosuppressive treatment, respectively.

The biggest constraint concerning the use of $\mathrm{AmB}$ in the clinic is its intrinsic host toxicity. This dose-related toxicity limits the maximum tolerated dose to for example $0.7-1.0 \mathrm{mg} / \mathrm{kg} / \mathrm{day}$ for AmB deoxycholate, which may be suboptimal to acquire clinical success [11]. Although the affinity of AmB to fungal ergosterol is over ten-fold higher compared to mammalian cholesterol, non-selective disruption of mammalian cell membranes does occur [26]. Renal toxicity and acute infusion-related adverse effects such as fever and nausea are most commonly associated with intravenous AmB administrations, while liver damage occurs but is less common [13]. Acute infusion-related toxicity is due to the fact that AmB, a molecule of microbial origin, is recognized by TLR2 (Toll-like receptor 2) and CD14 on mononuclear immune cells, leading to the initiation of an inflammatory response [11]. Nephrotoxicity is thought to be caused by increased exposure of AmB to renal cells via low-density lipoprotein (LDL) receptor mediated endocytosis. Moreover, $\mathrm{AmB}$ causes vasoconstriction in afferent renal arterioles, which decreases renal blood flow and glomerular filtration [11]. Lipid-associated AmB formulations, such as AmB lipid complex (ABLC) and liposomal AmB (L-AmB), have been developed with the main goal of improving the therapeutic index and reducing toxic complications compared to conventional AmB deoxycholate [11]. The pharmacokinetic parameters for these formulations differ substantially. For example, ABLC is large and taken up rapidly by macrophages in tissues such as the liver, spleen and lungs, while L-AmB is small and negatively charged, resulting in higher peak plasma levels compared to other formulations [11]. The effects of these lipid formulations on the clinical success and mortality of the patient are a subject of debate, and largely depend on the study, varying for type of infection (e.g., cryptococcosis and histoplasmosis) and background of the patients (e.g., AIDS and neutropenic) [11]. Overall, lipid AmB formulations show less nephrotoxicity compared to AmB deoxycholate, while L-AmB also exhibits less infusion-related reactions [11]. Still, new structures and formulations are developed to optimize the use of polyenes in the clinic. A recent example is the discovery of amphamide, an amide of AmB and termed a "second generation polyene antifungal" [27]. Amphamide was developed to increase the water solubility of AmB and shows an over 20-fold higher therapeutic index compared to AmB. Additionally, it has a superior antifungal activity and lower acute host toxicity in vivo [27]. Nanotechnology-based formulations of polyenes have also been investigated, aimed at decreasing their toxicity and/or increase their solubility, therapeutic index and/or oral availability. Nanoformulations include nanocrystals, nanotubes, polymeric nanocarriers, cubosomal and cochleate nanoparticles [28]. Although the low solubility and gastrointestinal absorption initially redeemed polyenes as oral drugs, recent research such as nanobody delivery shows great potential for the future [28,29]. 


\section{Mode of Action of Polyene Antifungal Drugs}

\subsection{Polyene-Sterol Interactions}

Overall, polyenes have an unusual mode of action compared to other antifungal drug classes, as they do not target a specific enzyme but rather interact with a vital molecule-ergosterol [1]. The first indications of the mode of action of polyenes were published in 1958, when Gottlieb et al. [30] discovered that the addition of sterols such as cholesterol, lanosterol and ergosterol could inhibit the fungicidal effect of nine polyenes including filipin, AmB and nystatin on three fungal species. They suggested that polyenes could prevent the synthesis of sterols (as the, then not yet discovered, azole, allylamine and phenylmorpholine antifungals do [1]) or competitively replace the sterols as a cofactor of an essential metabolic reaction [30]. Later, however, it became apparent that polyenes can alter the permeability of the membrane by reacting with sterols [10]. How this process of sterol sequestration works, remains subject to debate. The most studied mechanism of action is the pore forming model (see Section 3.2. Pore Forming Models) in which polyenes interact with ergosterol to form ion-leaking pores in the membrane [19]. Nevertheless, it has been shown that pore formation can also be established in the absence of sterols [31]. Early on, Cotero et al. [31] proposed that sterols have an essential role in the structure of the membrane itself during amphotericin activity, but might not be directly involved in the pore formation [31]. Later, other studies supported this idea [32-37]. For example, the polyene natamycin was shown to bind ergosterol without altering the cell membrane permeability [37]. Further research pointed out that natamycin inhibits various ergosterol-dependent membrane proteins and so disturbs essential cellular processes such as glucose transport, amino acid transport [38] and vacuolar fusion [36]. Currently, four models of the polyene mode of antifungal action have been proposed: the pore forming model, the surface adsorption model, the sterol sponge model and the oxidative damage model [39] (see Section 3.2 Pore Forming Models, Section 3.3 Surface Adsorption and Sterol Sponge Models and Section 3.4 Other Modes of Action).

In every proposed model, the binding of the polyene with ergosterol is key to its antifungal effect [39]. Ergosterol plays an essential role in many cellular processes of fungi, including regulation of membrane proteins, endocytosis, cell division, membrane fluidity and cell signaling [40-42]. The specificity of therapeutic polyenes to ergosterol comes from the fact that ergosterol has a significantly different three-dimensional structure compared to mammalian cholesterol, enabling better binding into the hydrophobic "pocket" of polyenes such as AmB, as depicted in Figure 2 [1]. Three interactive forces play a role in the binding of AmB and ergosterol: Van der Waals powers which are highest when both molecules are orientated co-planar and parallel, a hydrogen bond network between the $3 \beta-\mathrm{OH}$ group of the sterol and the polar mycosamine group of $\mathrm{AmB}$ and $\pi-\pi$ electronic interactions between the ergosterol side chain and the polyene "tail" of AmB [43]. The latter essential "attach point" does not occur when AmB binds to cholesterol [39,43]. Moreover, Van Der Waals interactions are weaker between cholesterol and AmB due to the sigmoidal conformation of the sterol side-chain [39]. The specific binding, along with the higher ergosterol:phospholipid ratio in fungal cell membranes, compared to the cholesterol:phospholipid ratio in mammalian cells, explains the selectivity of most polyenes to fungal cells [1]. 


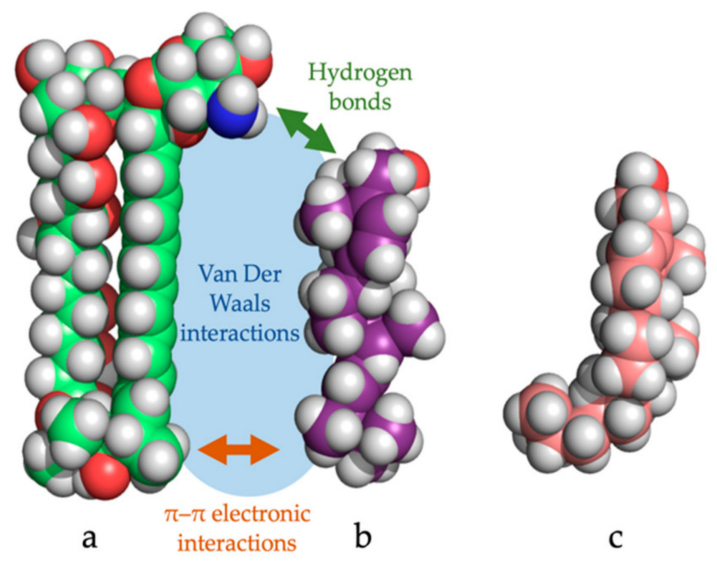

Figure 2. Three-dimensional model of amphotericin B (a) with the cylindrical ergosterol (b) and sigmoidal cholesterol (c). The three types of non-covalent interactions between amphotericin B and ergosterol are shown.

\subsection{Pore Forming Models}

The most studied model for polyene action is the pore formation model, in which polyenes and ergosterol interact to form an ion channel-like complex that leaks ions and small organic molecules from the cell, eventually leading to cell death [19]. Based on the amphipathic properties of polyenes, they would orientate in the plasma membrane with their hydrophobic polyene "tail" interacting with ergosterol, directed to the inner lipid environment of the membrane, while the hydrophilic polyol portion would form an aqueous channel, as illustrated in Figure 3A,B. Intermolecular hydrogen bonds between amino and carboxyl groups of the hydrophilic "heads" of neighboring polyene molecules further stabilize this channel [19]. Neutron diffraction studies have confirmed that such an architecture can exist when AmB interacts with ergosterol [44]. Typically, 4 to 12 polyene monomers would form a pore [39]. As the length of $A m B$ is almost equal to the length of a membrane phospholipid on average, two types of channels can be made: a full pore consisting of two ring complexes of polyenes (see Figure 3A) and a "half-pore", containing only one polyene ring (see Figure 3B). Both types essentially have the same structure but the latter would induce a conformational thinning of the lipid bilayer [19].

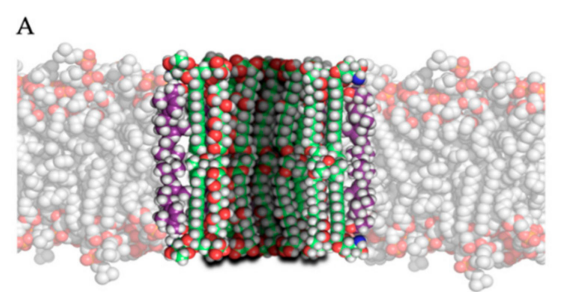

C

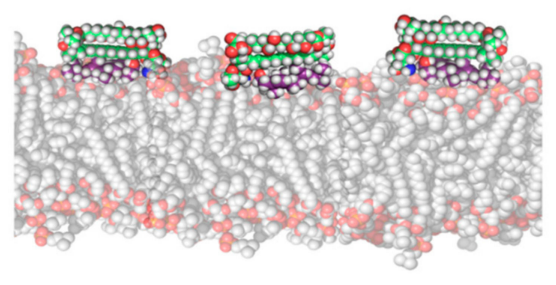

B

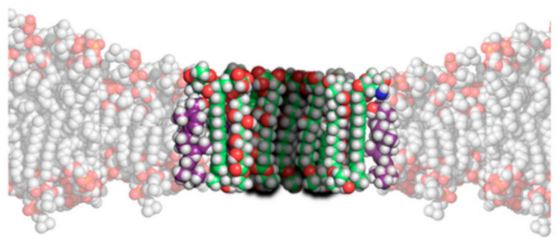

$\mathrm{D}$

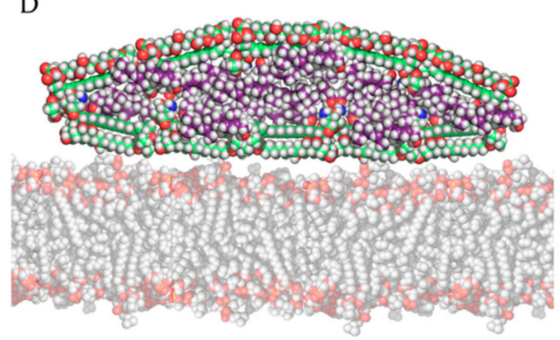

Figure 3. Four mechanistic models of the interaction of amphotericin B with ergosterol in/near the plasma membrane: (A) the pore forming model, (B) the half-pore forming model, $(\mathbf{C})$ the surface adsorption model and (D) the sterol sponge model (Legend: see Figure 2). 
Which pore is formed would primarily depend on the polyene, and the composition and thus thickness of the membrane [19]. For example, AmB would primarily form half-pores in a membrane mainly composed of dimyristoylphosphatidylcholine (DMPC) [45]. Pores are only formed after a certain threshold of polyene molecules in the membrane is reached. Below this threshold, aggregate complexes termed "non-aqueous pores" or "cation-selective pores" can increase the membrane permeability to monovalent cations, while true pores and half-pores can also transport larger nonelectrolyte molecules [46]. This threshold is significantly lower (by factor 5-10) in ergosterol containing membranes, compared to cholesterol containing membranes [46]. Moreover, patch clamp experiments with artificial $\mathrm{AmB}$ channels have shown that the ion transport occurs faster (a shorter channel "dwell time") in ergosterol containing membranes compared to cholesterol containing membranes [47], showcasing their antifungal specificity. The diameter of the pore determines the selectivity of transport or "leakage" out of the cell and depends on the type and concentration of polyene, while sterol type and sterol concentration have minor influences $[19,39,48]$. This is shown in the study by Yang et al., in which the channel diameter increases 100-fold when the concentration of AmB multiplies with factor 40 in an ergosterol-rich membrane [48]. In general, $\mathrm{AmB}$ forms relatively wide pores (approximately $0.46 \mathrm{~nm}$ ) and can transport molecules as big as sucrose, while nystatin forms smaller pores (approximately $0.36 \mathrm{~nm})[19]$.

\subsection{Surface Adsorption and Sterol Sponge Models}

The second and third models for polyene mode of action both hypothesize that, by adsorption or extraction of ergosterol from the membrane, the phospholipid membrane is destabilized, and essential cellular processes such as endocytosis and regulation of membrane protein function are disturbed [19]. Polyenes could adsorb ergosterol molecules to the "surface" of the phospholipid bilayer as illustrated in Figure 3C, termed the "surface adsorption model" [33,49]. In light of this theory, Anderson and colleagues [32] conducted a series of NMR studies to determine the localization and structure of AmB interacting with ergosterol, and they observed that these complexes are not (always) inserted in the membrane and can form extra-membranous aggregates. They suggested that in such a mechanism, large aggregates of parallelly positioned $\mathrm{AmB}$ molecules can form at the membrane, functioning as a "sterol sponge" [32] as illustrated in Figure 3D. Extracting ergosterol from the membrane in such a "sponge" would perturbate a vast array of ergosterol-dependent cellular processes, many of which governed by membrane proteins that directly bind to ergosterol. This might also explain why resistance to polyenes is rarely observed, as in resistant cells an alternative membrane sterol such as lanosterol (a precursor of ergosterol) will probably malfunction in these processes and reduce the fitness and pathogenicity of the cell [32]. Anderson et al. [32] also suggest that the extraction of cholesterol by large extra membranous aggregates of $\mathrm{AmB}$ is the primary cause of toxicity of this drug towards mammalian cells and thus, optimizing the binding affinity of AmB derivatives to ergosterol could significantly improve its therapeutic efficacy. Some remarks have to be made regarding the sterol sponge model proposed by Anderson et al. [32]. First, the ergosterol-to-lipid ratio used in their experimental set-up is different from the one observed in natural systems [39]. As the ergosterol-to-lipid ratio is essential regarding the polyene susceptibility of fungi, this might play a vital role. Secondly, it has been proven that, in a cholesterol-saturated environment such as the mammalian cell membrane, the thermodynamical balance between ergosterol-AmB vs. cholesterol-AmB would shift towards the latter, meaning that the "sterol sponge" would be saturated with cholesterol rather than ergosterol. A third argument against this model is that fungi have a rigid hydrophilic cell wall composed of polymers of chitin that might prevent the passage of hydrophobic ergosterol and so the formation of super-aggregates or "sponges" outside the cell wall [39].

Ion channel formation, small membrane-spanning aggregates and large extra-membranous aggregates may exist at the same time [32], although the chemical structure of the polyene probably influences the primary mode of action. Several studies have shown that the elimination of the C35 hydroxyl group of AmB does not alter the sterol-adsorption capacity and cytotoxic effect of the 
molecule but eliminates its pore-forming capacity [33,50]. It was suggested that the ability to form pores depends on the dimensions of the polyene macrolactone ring and, therefore, polyenes can be divided into non-pore forming polyenes (e.g., natamycin) and the pore-forming polyenes (e.g., AmB and nystatin) [19].

\subsection{Other Proposed Modes of Action}

Several observations point towards oxidative damage as an additional mode of action of $A m B$ [51,52]. One example is the rescue effect of hypoxia, exogenous catalase and super oxide dismutase (SOD) during AmB treatment of $C$. albicans without hindering AmB induced $\mathrm{K}^{+}$-leakage [52]. Another example is the enhanced resistance to oxidative damage by $\mathrm{H}_{2} \mathrm{O}_{2}$ of $\mathrm{AmB}$ resistant $C$. albicans strains [51]. Currently, several studies have provided evidence that polyenes can induce oxidative stress and cause DNA damage, protein carbonylation and lipid peroxidation, eventually leading to or contributing to cell death in fungi [53]. Moreover, metabolomic analysis of C. albicans exposed to $\mathrm{AmB}$ pointed out that $\mathrm{AmB}$ induced cell death was attenuated through increased production of polyamines such as putrescine, spermidine and spermine which have a role in scavenging reactive oxygen species (ROS) [54]. This is supported by gene expression analysis of C. albicans exposed to AmB, showing an increased expression of stress-related genes besides genes involved in membrane sterol homeostasis [55]. In Cryptococcus neoformans, it was shown that, after addition of AmB, cells become metabolically inactive and encounter a strong oxidative burst suggested to contribute to AmB induced cell death apart from membrane interactions and pore formation [35]. How this oxidative stress is exactly caused is still not clear, although it was suggested that polyene binding to the membrane triggers this response that leads to an apoptotic such as phenotype that includes ROS production or that, since AmB auto-oxidizes and forms free radicals [56], the antifungal itself causes oxidative stress [35]. In the latter model, the oxidative stress effect of polyenes would be distinct from its membrane permeabilization properties, although the free radicals produced would affect the membrane itself through lipid peroxidation [35].

\section{Drug Resistance to Polyenes}

Although polyenes have been used for many decades [5], polyene resistance is still rare compared to resistance to other antifungal drugs [20]. One explanation for this is the fact that it is often associated with severe fitness trade-offs [20]. Another hypothesis is that, compared to most other antifungals, polyenes target a major cell membrane component instead of an essential enzyme. Nevertheless, several mechanisms of resistance have been proposed (Figure 4) as described in Section 4.1. Molecular Mechanisms of Resistance, and several pathogenic fungi species are known to possess intrinsic resistance or are able to acquire resistance to polyenes in the clinic, as described in Section 4.2. Epidemiology of Polyene Resistance.

\subsection{Molecular Mechanisms of Resistance}

The most common mechanism of acquired $\mathrm{AmB}$ resistance is attributed to alterations in the sterol composition of the fungal cell membrane $[57,58]$. Several mutations in genes of the ergosterol biosynthesis pathway (ERG genes) have been associated with this mechanism. In C. albicans, the loss of function of ERG11 and ERG3 genes (lanosterol 14 $\alpha$-demethylase and C-5 sterol desaturase, respectively) leads to the exchange of ergosterol for alternate sterols such as lanosterol, eburicol and 4,14-dimethyl-zymosterol in the membrane [20,58]. In other reports, $\mathrm{AmB}$ resistance in C. albicans is associated with a substitution in ERG11 and loss of function of ERG5 (C-22 sterol desaturase), again associated with an alternate membrane sterol composition [20,59]. In other Candida spp., inactivation of ERG6 (C-24 sterol methyl-transferase) [60,61] and ERG2 (C-8 sterol isomerase) [61] were found to have a similar effect. A mutation in ERG2 resulting in its inactivation, is one of the only described mechanisms of AmB resistance in C. neoformans [62]. Nevertheless, high AmB resistance (MIC $20 \mu \mathrm{g} / \mathrm{mL}$ ) without significant alterations in ergosterol biosynthesis have been reported 
in experimentally evolved C. neoformans, suggesting that sterol-independent mechanisms of AmB resistance also exist in Cryptococcus spp. [63]. Isolates of the Candida haemulonii species complex (C. haemulonii, C. haemulonii var. vulnera and C. duobushemulonii), known for their increased AmB resistance, have been shown to possess a cell membrane with an altered sterol profile similar to AmB resistant species with ERG11, ERG3 ERG2 and ERG6 mutations [64]. Given the severe fitness deficits of mutations in the ergosterol biosynthesis pathway [20], AmB resistance is rarely found in combination with resistance to other antifungal drugs, although certain polyene resistance inducing ERG mutations can result in cross resistance to azoles $[58,65,66]$. A well-known example of this occurs upon inactivation of the target of azoles ERG11 and ERG3, resulting in the abrogation of the biosynthesis of ergosterol and inhibition of the synthesis of the toxic sterol 14-methyl-3,6-diol, respectively [58].

The growing interest in the role of oxidative stress in the fungicidal effects of AmB has led to an increase in research concerning stress related mechanisms of resistance. It is hypothesized that a reduction in polyene induced oxidative stress might allow the cell to better tolerate AmB exposure [53,67]. In intrinsically AmB resistant fungal pathogens such as A.terreus, this mechanism of resistance appears to be more important than an altered membrane sterol composition [67]. Compared to AmB susceptible Aspergillus fumigatus, intrinsically resistant $A$. terreus shows only a slight increase in membrane ergosterol levels, but a significant increase in catalase levels [68]. As research shows, a catalase-based mechanism of resistance counteracting AmB-induced oxidative stress that would otherwise result in cell death, is likely [35,51-53]. Catalase activity might break down the harmful ROS produced during AmB treatment and so protect the cell [69]. Further evidence supporting this hypothesis was given by Blatzer et al. [70], who found a severe induction of mitochondrial ROS generation upon AmB exposure in rare susceptible isolates of $A$. terreus, compared to resistant isolates [67]. Another mechanism of stress tolerance and/or resistance upon AmB exposure is likely governed by the molecular chaperone heat shock protein 90 (Hsp90), a highly connected, central factor in cellular stress responses that possibly potentiates the acquisition of resistance by regulating a myriad of client proteins [71,72]. Cowen et al. [72] hypothesize the involvement of Hsp90 in the emergence and/or maintenance of resistance via different possible mechanisms: (i) the disruption of Hsp90 might allow the persistence of new genetic variations, (ii) active Hsp90 might stabilize mutated cell regulators that have the ability to induce resistance but are prone to misfolding or (iii) Hsp90 might chaperone unmutated regulators of cell signaling (e.g., calcineurin), thereby allowing the development of adaptive phenotypes [72]. The connection between Hsp90 and antifungal resistance can be investigated through the use of Hsp90 inhibitors such as geldanamycin and radicicol [73,74]. In fluconazole resistant strains, modest inhibition of Hsp90 leads to abrogation of resistance but has no effect on cell growth [72]. Interestingly, inhibition of Hsp90 in AmB resistant cells does lead to inhibition of growth, even in the absence of AmB [20]. Blatzer et al. [75] found a correlation between AmB resistance in $A$. terreus and another family of chaperones: the Hsp70 family. They identified higher basal levels of expression of several Hsp70 genes in resistant strains and observed an instant activation of the majority of Hsp70 genes in the resistant $A$. terreus isolates upon exposure to AmB. Inhibition of Hsp70 only had limited effects on AmB susceptible A. terreus isolates, while it led to a considerable increase in susceptibility for resistant isolates [75]. Overall, these observations indicate a possibly essential role for the molecular chaperones of the Hsp90 and Hsp70 family in the acquisition and/or maintenance of AmB resistance [20,75].

In addition to alterations of the membrane sterol composition and regulation of oxidative stress, some reports show a correlation between $\mathrm{AmB}$ resistance and alterations of the fungal cell wall. In 1999, Seo et al. [76] acquired an experimentally evolved Aspergillus flavus isolate that was able to grow in concentrations of up to $100 \mu \mathrm{g} / \mathrm{mL} \mathrm{AmB} \mathrm{[76].} \mathrm{An} \mathrm{alteration} \mathrm{of} \mathrm{the} \mathrm{cell} \mathrm{wall} \mathrm{was} \mathrm{suggested}$ to be an important mechanism contributing to this resistance. The main change in the fungal cell wall composition was reported to be an increase in the 1,3- $\alpha$-glucan fraction [76]. More recently, an $\mathrm{AmB}$ resistant $C$. tropicalis isolate was also found to have an enlarged cell wall with increased levels of 1,3- $\beta$-glucan [77]. Although the increased glucan production could be the result of regulatory 
mechanisms affected by AmB exposure or resistance [76], another hypothesis is that the glucan molecules can physically inhibit the penetration of AmB through the cell wall [76]. In addition to increased AmB resistance, the cells with an enlarged cell wall also elicited a different immune response compared to susceptible cells. Mesa-Arango et al. [77] suggest that the increased 1,3- $\beta$-glucan is proportional to the strength of the immune response and contributes to prolonged survival of resistant clones since an exaggerated proinflammatory response can reduce the efficiency of immune clearance of a systemic infection $[77,78]$.

The active efflux of drugs, a common mechanism of resistance for azole drugs, does not appear to play a role for polyene resistance. Although one report indicates an increased AmB tolerance in C. albicans upon the overexpression of drug efflux pump Cdr1 [79], this was later contradicted by Niimi et al. [80], who did not find a correlation between Cdr1 overexpression and polyene resistance.

Although multiple mechanisms of resistance have been proposed, the molecular mechanisms driving a reduced polyene susceptibility are not always clear. This is showcased by the emergent C. auris, in which an AmB resistance prevalence of up to 30\% [81-83] has been found among clinical isolates, but still sequencing efforts cannot identify driving mutations. Differential expression of $E R G$ genes might be involved, as Munoz et al. [84] showed an upregulation of ERG13, ERG6, ERG2 and ERG1 upon AmB exposure in AmB resistant C. auris isolates, compared to susceptible strains [84]. Escandon and colleagues [18] sequenced AmB resistant $C$. auris strains of Colombia and identified a mutation in a gene encoding a homolog of C. albicans FLO8. Flo8 is a transcription factor that has multiple downstream effectors, and it has been proven to positively regulate ERG11 expression in yeast [85]. A recent study by Carolus et al. [86] also identified a mutation in FLO8 in an AmB resistant C. auris strain that was experimentally evolved. Although this mutation did not significantly alter the AmB MIC, it raises questions regarding the link between $F L O 8$ and $\mathrm{AmB}$ resistance in C.auris. The same strain from Carolus et al. [86] also acquired nonsense mutations in both ERG11 and ERG3, significantly decreasing the AmB susceptibility with cross resistance towards azoles [86]. Additionally, a mutation was found in a gene predicted to encode the DNA damage checkpoint protein Mec3 [86], part of the Rad17p-Mec3p-Ddc1p sliding clamp [87]. As AmB evokes oxidative damage to DNA that leads to apoptosis [53], DNA damage checkpoint proteins might be involved in AmB resistance, although this link has not been confirmed. Due to these and other loose ends, further research into the mechanisms of polyene resistance, especially in the context of pan resistance as found in C. auris [81,88,89], Fusarium [90-92] and Scedosporium spp. [93-96], is highly needed [97,98]. 


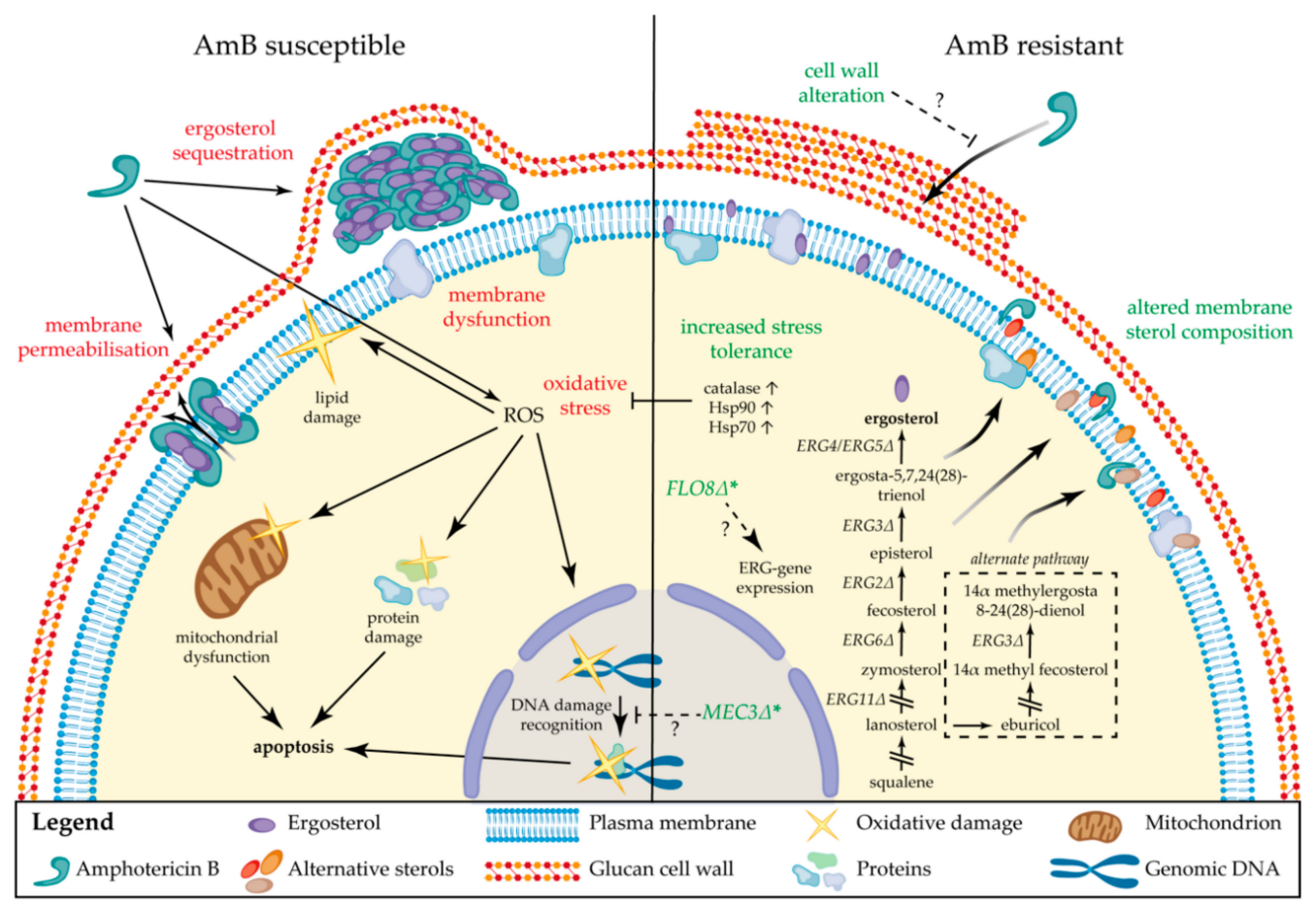

Figure 4. Schematic overview of the amphotericin B modes of action and drug resistance mechanisms in fungal cells. * association exists but has not been validated. See text for explanation. Gene names with delta symbol indicate mutations and not full deletions.

\subsection{Epidemiology of Polyene Resistance}

AmB resistance occurs in both yeasts and molds [99-104]. C. albicans, the most common cause of human candidiasis, rarely shows resistance to polyenes, although resistant strains have been found in antifungal susceptibility surveillance studies $[21,101,105,106]$. Similarly, Candida glabrata, Candida parapsilosis, Candida guilliermondii, Candida kefyr and Candida dubliensis are generally considered to be susceptible to AmB, with most surveillance studies reporting an AmB susceptibility rate close to $100 \%$ [21,100,101,105-112]. Candida tropicalis [102,107,109,111] and Candida krusei $[21,102,105,106]$ are often found to be AmB susceptible, but some reports show AmB resistance, with higher rates in C. krusei [107,111,112] compared to C. tropicalis [112]. Reports on AmB resistance in Candida lusitaniae range from relatively frequent [113-115] to similar resistance rates compared to other Candida spp. [102,116-118]. In comparison to to the previously mentioned Candida spp., C. auris $[81,88]$ and species of the C. haemulonii complex [119-122] are frequently observed to be AmB resistant. These emergent Candida spp. are closely related and show strong tendencies towards intrinsic and/or acquired resistance to $\mathrm{AmB}[81,88,119,123]$. For C. auris, $\mathrm{AmB}$ resistance rates range from $8 \%$ [88] up to $23 \%$ [81]. Among the $C$. haemulonii species complex, resistance rates are even higher, with one study reporting a high AmB MIC for 12 out of 28 isolates [120]. Other reports [119,121,122] confirm a high rate of polyene resistance in $C$. haemulonii complex spp., suggesting an intrinsic resistance to AmB. In general, C. duobushaemulonii exhibits the highest MICs for AmB, often reaching twice the MIC of C. haemulonii [119-122]. C. neoformans and C. gattii are the most common, pathogenic non-Candida yeasts [124,125], but AmB resistance in Cryptococcus spp. is rare, with resistance rates varying from 0\% to 5.8\% for C. neoformans and C. gattii, respectively [126-133]. Regarding species of the Trichosporon genus, Trichosporon asahii (formerly $T$. beigelii) is most frequently found to infect humans [134,135]. T. asahii shows the ability to acquire extensive resistance to $\mathrm{AmB}$, reaching resistance rates of over $50 \%$ [136-141]. Other pathogenic yeasts not mentioned here are less clinically relevant and/or are generally susceptible to AmB [142]. 
Among pathogenic molds, Aspergillus spp. are well known for their extensive AmB resistance. For A. fumigatus, the most common cause of invasive aspergillosis [143-146], recent studies have shown the ability to efficiently acquire AmB resistance with rates ranging from 43\% [144] to 96.4\% [146]. Widespread AmB resistance is also found among other common Aspergillus spp. such as A. flavus (resistance rate ranges from 12.5\% [147] up to 87\% [144]) and intrinsic AmB resistance is well recognized in A. terreus [67]. Furthermore, intrinsically resistant isolates have been suggested for several other Aspergillus spp. such as A. flavus [145,148] and Aspergillus lentulus [145,149]. It should be noted that some studies [150] report a low incidence of AmB resistance in Aspergillus spp. Baddley et al. [151] report, for example, low AmB MICs for $93.3 \%$ of the investigated Aspergillus spp. isolates with increased MICs only in A. terreus [151]. Other filamentous fungi such as Scedosporium apiospermum and Lomentospora prolificans (formerly Scedosporium prolificans) have also been identified as intrinsically AmB resistant and, therefore, often require complex antifungal treatments [93-95,152,153]. Additionally, some Fusarium spp. have been reported as intrinsically resistant to AmB [90-92,154]. While AmB is usually recommended for treating invasive fusariosis [13], Fusarium solani, a prevalent Fusarium spp. often shows increased AmB MICs $[155,156]$. Other members of the Fusarium genus are generally susceptible to AmB. Sporothrix schenkii is usually observed to be susceptible to AmB although some resistant isolates have been found [157]. Furthermore, several reports indicate increased AmB MICs for the hyphal form of this pathogen compared to the yeast form [158-160], complicating clinical interpretation [158]. Histoplasma capsulatum exhibits very low MICs for AmB, making it a preferred treatment for this pathogenic mold [161,162]. Although AmB resistance is rare for isolates of Mucorales [163-165], some Rhizopus and Cunninghamella strains show decreased AmB susceptibility [103,166], with one report showing decreased AmB susceptibility in 3 out of 19 and 5 out of 8 isolates tested, respectively [167].

A major challenge in investigating the epidemiology of polyene resistance is the lack of clear susceptibility breakpoints for most fungal pathogens. Park et al. [168] showed that the commonly used breakpoint of $2 \mu \mathrm{g} / \mathrm{mL}$ for Candida spp. does not always correlate with the clinical outcome of AmB treatment. Rex et al. [169] showed similar results and even observed an inversely proportional trend, where lower MIC values were associated with increased failure of treatment in the clinic. Nonetheless, some studies report a positive correlation between AmB MIC and treatment success [170,171]. For most fungal species, no clinical breakpoints have been determined, thus forcing researchers to resort to epidemiological cutoff values to distinguish resistant from susceptible isolates. These conflicting observations complicate and question the interpretation of resistance epidemiology and its clinical significance.

\section{Conclusions}

Although discovered over 70 years ago, and despite their inherent toxic nature, polyene antifungals are still part of the first-line treatment for various types of invasive fungal infections. This showcases both the predicament of the antifungal drug discovery pipeline and the potency of polyenes as antifungal drugs. Polyenes have been used in the clinic over several decennia but still, debates are ongoing regarding their modes of action, and the mechanisms of resistance are arguably the least understood compared to other commonly used antifungal drugs such as azoles and echinocandins. Emergent polyene resistant pathogens such as $C$. auris, for which hardly any reports on resistance mechanisms exist despite a high incidence of resistance in the clinic, urge to fill those knowledge gaps. A multitude of recent reports show the interest in further development of AmB formulations, including oral drug development, to facilitate use and increase treatment efficacy. Especially due to their broad spectrum, rare incidence and relatively weak potency of resistance development, polyenes could still be described as a "diamond in the rough" in the current antifungal drug resistance crisis. Nonetheless, for polyenes to be on the forefront of this battle, further research into their mode of action, drug resistance and clinical application is key.

Author Contributions: Writing—original draft preparation: H.C. and S.P. (equal contribution); writing—review and editing, H.C., S.P., K.L. and P.V.D. All authors have read and agreed to the published version of the manuscript. 
Funding: This work was supported by a Fund for Scientific Research Flanders (FWO), personal research grant nr. $11 \mathrm{D} 7620 \mathrm{~N}$ awarded to H.C.

Acknowledgments: We would like to thank Nico Vangoethem for assistance with figure design in Adobe Illustrator ${ }^{\circledR}$ and Dimitrios Sofras for assistance with figure design in PyMOL and ChemDraw.

Conflicts of Interest: The authors declare no conflict of interest.

\section{References}

1. Odds, F.C.; Brown, A.J.P.; Gow, N.A.R. Antifungal agents: Mechanisms of action. Trends Microbiol. 2003, 11, 272-279.

2. Zotchev, S.B. Polyene macrolide antibiotics and their applications in human therapy. Curr. Med. Chem. 2003, 10, 211-223. [PubMed]

3. Dixon, D.M.; Walsh, T.J. Antifungal Agents. In Medical Microbiology, 4th ed.; University of Texas Medical Branch at Galveston: Galveston, TX, USA, 1996.

4. Hazen, E.L.; Brown, R. Fungicidin, an antibiotic produced by a soil actinomycete. Proc. Soc. Exp. Biol. Med. 1951, 76, 93-97. [CrossRef] [PubMed]

5. Lattif, A.A.; Swindell, K. History of Antifungals. In Antifungal Therapy; Ghannoum, A.M., Perfect, R.J., Eds.; CRC Press: Boca Raton, FL, USA, 2009; Volume 1.

6. Espinell-Ingroff, A. Medical Mycology and Training in the United States: A Historical Analysis (1894-1996); Springer Science \& Business Media: Berlin/Heidelberg, Germany, 2003.

7. Dutcher, J.D. The discovery and development of amphotericin B. Dis. Chest 1968, 54, $296-298$.

8. Borowski, E.; Zieliński, J.; Ziminski, T.; Falkowski, L.; Kołodziejczyk, P.; Golik, J.; Jereczek, E.; Adlercreutz, H. Chemical studies with amphotericin B III. The complete structure of the antibiotic. Tetrahedron Lett. 1970, 11, 3909-3914.

9. Hamilton-Miller, J. Chemistry and biology of the polyene macrolide antibiotics. Bacteriol. Rev. 1973, $37,166$.

10. Kinsky, S.C. Polyene Antibiotics. In Antibiotics; Springer: Berlin/Heidelberg, Germany, 1967; pp. $122-141$.

11. Hamill, R.J. Amphotericin B formulations: A comparative review of efficacy and toxicity. Drugs 2013, 73, 919-934.

12. Saravolatz, L.D.; Bern, C.; Adler-Moore, J.; Berenguer, J.; Boelaert, M.; den Boer, M.; Davidson, R.N.; Figueras, C.; Gradoni, L.; Kafetzis, D.A. Liposomal amphotericin B for the treatment of visceral leishmaniasis. Clin. Infect. Dis. 2006, 43, 917-924.

13. Chandrasekar, P. Management of invasive fungal infections: A role for polyenes. J. Antimicrob. Chemother. 2011, 66, 457-465.

14. Cornely, O.A.; Vehreschild, J.J.; Ullmann, A.J. Is there a role for polyenes in treating invasive mycoses? Curr. Opin. Infect. Dis. 2006, 19, 565-570.

15. Stone, N.R.; Bicanic, T.; Salim, R.; Hope, W. Liposomal amphotericin B (AmBisome ${ }^{\circledR}$ ): A review of the pharmacokinetics, pharmacodynamics, clinical experience and future directions. Drugs 2016, 76, 485-500. [PubMed]

16. Steinbach, W.J.; Benjamin, D.K., Jr.; Kontoyiannis, D.P.; Perfect, J.R.; Lutsar, I.; Marr, K.A.; Lionakis, M.S.; Torres, H.A.; Jafri, H.; Walsh, T.J. Infections due to Aspergillus terreus: A multicenter retrospective analysis of 83 cases. Clin. Infect. Dis. 2004, 39, 192-198. [PubMed]

17. Steinbach, W.J.; Schell, W.A.; Miller, J.L.; Perfect, J.R. Scedosporium prolificans osteomyelitis in an immunocompetent child treated with voriconazole and caspofungin, as well as locally applied polyhexamethylene biguanide. J. Clin. Microbiol. 2003, 41, 3981-3985. [PubMed]

18. Escandon, P.; Chow, N.A.; Caceres, D.H.; Gade, L.; Berkow, E.L.; Armstrong, P.; Rivera, S.; Misas, E.; Duarte, C.; Moulton-Meissner, H.; et al. Molecular epidemiology of Candida auris in Colombia reveals a highly related, countrywide colonization with regional patterns in amphotericin B resistance. Clin. Infect. Dis. 2019, 68, 15-21. [CrossRef] [PubMed]

19. Kristanc, L.; Božič, B.; Jokhadar, Š.Z.; Dolenc, M.S.; Gomišček, G. The pore-forming action of polyenes: From model membranes to living organisms. Biochim. Biophys. Acta (BBA)-Biomembr. 2019, 1861, 418-430.

20. Vincent, B.M.; Lancaster, A.K.; Scherz-Shouval, R.; Whitesell, L.; Lindquist, S. Fitness trade-offs restrict the evolution of resistance to amphotericin B. PLoS Biol. 2013, 11, e1001692. 
21. Rambach, G.; Oberhauser, H.; Speth, C.; Lass-Flörl, C. Susceptibility of Candida species and various moulds to antimycotic drugs: Use of epidemiological cutoff values according to EUCAST and CLSI in an 8-year survey. Med. Mycol. 2011, 49, 856-863. [CrossRef]

22. Wiederhold, N.P. Antifungal resistance: Current trends and future strategies to combat. Infect. Drug Resist. 2017, 10, 249-259. [CrossRef]

23. Pappas, P.G.; Kauffman, C.A.; Andes, D.R.; Clancy, C.J.; Marr, K.A.; Ostrosky-Zeichner, L.; Reboli, A.C.; Schuster, M.G.; Vazquez, J.A.; Walsh, T.J.; et al. Clinical Practice Guideline for the Management of Candidiasis: 2016 Update by the Infectious Diseases Society of America. Clin. Infect. Dis. 2015, 62, e1-e50. [CrossRef]

24. Cornely, O.A.; Alastruey-Izquierdo, A.; Arenz, D.; Chen, S.C.A.; Dannaoui, E.; Hochhegger, B.; Hoenigl, M.; Jensen, H.E.; Lagrou, K.; Lewis, R.E.; et al. Global guideline for the diagnosis and management of mucormycosis: An initiative of the European Confederation of Medical Mycology in cooperation with the Mycoses Study Group Education and Research Consortium. Lancet Infect. Dis. 2019, 19, e405-e421. [CrossRef]

25. Walsh, T.J.; Anaissie, E.J.; Denning, D.W.; Herbrecht, R.; Kontoyiannis, D.P.; Marr, K.A.; Morrison, V.A.; Segal, B.H.; Steinbach, W.J.; Stevens, D.A. Treatment of aspergillosis: Clinical practice guidelines of the Infectious Diseases Society of America. Clin. Infect. Dis. 2008, 46, 327-360. [CrossRef]

26. Readio, J.D.; Bittman, R. Equilibrium binding of amphotericin B and its methyl ester and borate complex to sterols. Biochim. Biophys. Acta (BBA)-Biomembr. 1982, 685, 219-224. [CrossRef]

27. Tevyashova, A.N.; Bychkova, E.N.; Solovieva, S.E.; Zatonsky, G.V.; Grammatikova, N.E.; Isakova, E.B.; Mirchink, E.P.; Treshchalin, I.D.; Pereverzeva, E.R.; Bykov, E.E. Discovery of Amphamide, a Drug Candidate for the Second Generation of Polyene Antibiotics. ACS Infect. Dis. 2020, 6, 2029-2044. [CrossRef] [PubMed]

28. Liu, M.; Chen, M.; Yang, Z. Design of amphotericin B oral formulation for antifungal therapy. Drug Deliv. 2017, 24, 1-9. [CrossRef] [PubMed]

29. Cuddihy, G.; Wasan, E.K.; Di, Y.; Wasan, K.M. The development of oral amphotericin b to treat systemic fungal and parasitic infections: Has the myth been finally realized? Pharmaceutics 2019, 11, 99. [CrossRef]

30. Gottlieb, D.; Carter, H.E.; Sloneker, J.H.; Ammann, A. Protection of fungi against polyene antibiotics by sterols. Science 1958, 128, 361. [CrossRef]

31. Cotero, B.V.; Rebolledo-Antúnez, S.; Ortega-Blake, I. On the role of sterol in the formation of the amphotericin B channel. Biochim. Biophys. Acta (BBA)-Biomembr. 1998, 1375, 43-51. [CrossRef]

32. Anderson, T.M.; Clay, M.C.; Cioffi, A.G.; Diaz, K.A.; Hisao, G.S.; Tuttle, M.D.; Nieuwkoop, A.J.; Comellas, G.; Maryum, N.; Wang, S. Amphotericin forms an extramembranous and fungicidal sterol sponge. Nat. Chem. Biol. 2014, 10, 400. [CrossRef]

33. Gray, K.C.; Palacios, D.S.; Dailey, I.; Endo, M.M.; Uno, B.E.; Wilcock, B.C.; Burke, M.D. Amphotericin primarily kills yeast by simply binding ergosterol. Proc. Natl. Acad. Sci. USA 2012, 109, 2234-2239. [CrossRef]

34. Palacios, D.S.; Anderson, T.M.; Burke, M.D. A Post-PKS Oxidation of the Amphotericin B Skeleton Predicted to be Critical for Channel Formation Is Not Required for Potent Antifungal Activity. J. Am. Chem. Soc. 2007, 129, 13804-13805. [CrossRef]

35. Sangalli-Leite, F.; Scorzoni, L.; Mesa-Arango, A.C.; Casas, C.; Herrero, E.; Gianinni, M.J.S.M.; Rodríguez-Tudela, J.L.; Cuenca-Estrella, M.; Zaragoza, O. Amphotericin B mediates killing in Cryptococcus neoformans through the induction of a strong oxidative burst. Microbes Infect. 2011, 13, 457-467. [CrossRef] [PubMed]

36. Te Welscher, Y.M.; Jones, L.; Van Leeuwen, M.R.; Dijksterhuis, J.; De Kruijff, B.; Eitzen, G.; Breukink, E. Natamycin inhibits vacuole fusion at the priming phase via a specific interaction with ergosterol. Antimicrob. Agents Chemother. 2010, 54, 2618-2625. [CrossRef] [PubMed]

37. Te Welscher, Y.M.; ten Napel, H.H.; Balagué, M.M.; Souza, C.M.; Riezman, H.; De Kruijff, B.; Breukink, E. Natamycin blocks fungal growth by binding specifically to ergosterol without permeabilizing the membrane. J. Biol. Chem. 2008, 283, 6393-6401. [CrossRef] [PubMed]

38. Te Welscher, Y.M.; van Leeuwen, M.R.; de Kruijff, B.; Dijksterhuis, J.; Breukink, E. Polyene antibiotic that inhibits membrane transport proteins. Proc. Natl. Acad. Sci. USA 2012, 109, 11156-11159. [CrossRef] [PubMed]

39. Kamiński, D.M. Recent progress in the study of the interactions of amphotericin B with cholesterol and ergosterol in lipid environments. Eur. Biophys. J. 2014, 43, 453-467. [CrossRef] [PubMed]

40. Rodrigues, M.L. The multifunctional fungal ergosterol. mBio 2018, 9, e01755-18. [CrossRef] [PubMed]

41. Heese-Peck, A.; Pichler, H.; Zanolari, B.; Watanabe, R.; Daum, G.; Riezman, H. Multiple functions of sterols in yeast endocytosis. Mol. Biol. Cell 2002, 13, 2664-2680. [CrossRef] 
42. Jin, H.; McCaffery, J.M.; Grote, E. Ergosterol promotes pheromone signaling and plasma membrane fusion in mating yeast. J. Cell Biol. 2008, 180, 813-826. [CrossRef]

43. Baran, M.; Borowski, E.; Mazerski, J. Molecular modeling of amphotericin B-ergosterol primary complex in water II. Biophys. Chem. 2009, 141, 162-168. [CrossRef]

44. Foglia, F.; Lawrence, M.J.; Demee, B.; Fragneto, G.; Barlow, D. Neutron diffraction studies of the interaction between amphotericin B and lipid-sterol model membranes. Sci. Rep. 2012, 2, 778. [CrossRef]

45. Matsuoka, S.; Ikeuchi, H.; Matsumori, N.; Murata, M. Dominant formation of a single-length channel by amphotericin B in dimyristoylphosphatidylcholine membrane evidenced by $13 \mathrm{C}-31 \mathrm{P}$ rotational echo double resonance. Biochemistry 2005, 44, 704-710. [CrossRef] [PubMed]

46. Cohen, B.E. Amphotericin B membrane action: Role for two types of ion channels in eliciting cell survival and lethal effects. J. Membr. Biol. 2010, 238, 1-20. [CrossRef] [PubMed]

47. Ostroumova, O.S.; Efimova, S.S.; Schagina, L.V. Probing amphotericin B single channel activity by membrane dipole modifiers. PLoS ONE 2012, 7, e30261. [CrossRef] [PubMed]

48. Yang, T.-S.; Ou, K.-L.; Peng, P.-W.; Liou, B.-C.; Wang, W.-T.; Huang, Y.-C.; Tsai, C.-M.; Su, C.-H. Quantifying membrane permeability of amphotericin B ion channels in single living cells. Biochim. Biophys. Acta (BBA)-Biomembr. 2013, 1828, 1794-1801. [CrossRef] [PubMed]

49. Mouri, R.; Konoki, K.; Matsumori, N.; Oishi, T.; Murata, M. Complex formation of amphotericin B in sterol-containing membranes as evidenced by surface plasmon resonance. Biochemistry 2008, 47, 7807-7815. [CrossRef] [PubMed]

50. Szpilman, A.M.; Cereghetti, D.M.; Manthorpe, J.M.; Wurtz, N.R.; Carreira, E.M. Synthesis and Biophysical Studies on 35-Deoxy Amphotericin B Methyl Ester. Chem. Eur. J. 2009, 15, 7117-7128. [CrossRef] [PubMed]

51. Sokol-Anderson, M.; Sligh, J.E., Jr.; Elberg, S.; Brajtburg, J.; Kobayashi, G.S.; Medoff, G. Role of cell defense against oxidative damage in the resistance of Candida albicans to the killing effect of amphotericin B. Antimicrob. Agents Chemother. 1988, 32, 702-705. [CrossRef] [PubMed]

52. Sokol-Anderson, M.L.; Brajtburg, J.; Medoff, G. Amphotericin B-induced oxidative damage and killing of Candida albicans. J. Infect. Dis. 1986, 154, 76-83. [CrossRef]

53. Mesa-Arango, A.C.; Scorzoni, L.; Zaragoza, O. It only takes one to do many jobs: Amphotericin B as antifungal and immunomodulatory drug. Front. Microbiol. 2012, 3. [CrossRef]

54. Cao, Y.; Zhu, Z.; Chen, X.; Yao, X.; Zhao, L.; Wang, H.; Yan, L.; Wu, H.; Chai, Y.; Jiang, Y. Effect of amphotericin B on the metabolic profiles of Candida albicans. J. Proteome Res. 2013, 12, 2921-2932. [CrossRef]

55. Liu, T.T.; Lee, R.E.; Barker, K.S.; Lee, R.E.; Wei, L.; Homayouni, R.; Rogers, P.D. Genome-wide expression profiling of the response to azole, polyene, echinocandin, and pyrimidine antifungal agents in Candida albicans. Antimicrob. Agents Chemother. 2005, 49, 2226-2236. [CrossRef] [PubMed]

56. Lamp-Freund, M.T.; Ferreira, V.F.; Schreier, S. Mechanism of inactivation of the polyene antibiotic amphotericin B. J. Antibiot. 1985, 38, 753-757. [CrossRef] [PubMed]

57. Geber, A.; Hitchcock, C.A.; Swartz, J.E.; Pullen, F.S.; Marsden, K.E.; Kwon-Chung, K.J.; Bennett, J.E. Deletion of the Candida glabrata ERG3 and ERG11 genes: Effect on cell viability, cell growth, sterol composition, and antifungal susceptibility. Antimicrob. Agents Chemother. 1995, 39, 2708-2717. [CrossRef] [PubMed]

58. Sanglard, D.; Ischer, F.; Parkinson, T.; Falconer, D.; Bille, J. Candida albicans mutations in the ergosterol biosynthetic pathway and resistance to several antifungal agents. Antimicrob. Agents Chemother. 2003, 47, 2404-2412. [CrossRef] [PubMed]

59. Martel, C.M.; Parker, J.E.; Bader, O.; Weig, M.; Gross, U.; Warrilow, A.G.; Kelly, D.E.; Kelly, S.L. A clinical isolate of Candida albicans with mutations in ERG11 (encoding sterol 14 $\alpha$-demethylase) and ERG5 (encoding C22 desaturase) is cross resistant to azoles and amphotericin B. Antimicrob. Agents Chemother. 2010, 54, 3578-3583. [CrossRef] [PubMed]

60. Young, L.Y.; Hull, C.M.; Heitman, J. Disruption of ergosterol biosynthesis confers resistance to amphotericin B in Candida lusitaniae. Antimicrob. Agents Chemother. 2003, 47, 2717-2724. [CrossRef] [PubMed]

61. Ahmad, S.; Joseph, L.; Parker, J.E.; Asadzadeh, M.; Kelly, S.L.; Meis, J.F.; Khan, Z. ERG6 and ERG2 are major targets conferring reduced susceptibility to amphotericin B in clinical Candida glabrata isolates in Kuwait. Antimicrob. Agents Chemother. 2019, 63, e01900-18. [CrossRef]

62. Kelly, S.L.; Lamb, D.C.; Taylor, M.; Corran, A.J.; Baldwin, B.C.; Powderly, W.G. Resistance to amphotericin B associated with defective sterol $\Delta 8 \rightarrow 7$ isomerase in a Cryptococcus neoformans strain from an AIDS patient. FEMS Microbiol. Lett. 1994, 122, 39-42. [CrossRef] 
63. Joseph-Horne, T.; Loeffler, R.; Hollomon, D.; Kelly, S. Amphotericin B resistant isolates of Cryptococcus neoformans without alteration in sterol biosynthesis. J. Med. Vet. Mycol. 1996, 34, 223-225. [CrossRef]

64. Silva, L.N.; Oliveira, S.S.; Magalhães, L.B.; Andrade Neto, V.V.; Torres-Santos, E.C.; Carvalho, M.D.; Pereira, M.D.; Branquinha, M.H.; Santos, A.L. Unmasking the amphotericin B resistance mechanisms in Candida haemulonii species complex. ACS Infect. Dis. 2020, 6, 1273-1282. [CrossRef]

65. Joseph-Horne, T.; Hollomon, D.; Loeffler, R.; Kelly, S.L. Cross-resistance to polyene and azole drugs in Cryptococcus neoformans. Antimicrob. Agents Chemother. 1995, 39, 1526-1529. [CrossRef] [PubMed]

66. Kelly, S.; Lamb, D.; Kelly, D.; Manning, N.; Loeffler, J.; Hebart, H.; Schumacher, U.; Einsele, H. Resistance to fluconazole and cross-resistance to amphotericin B in Candida albicans from AIDS patients caused by defective sterol $\Delta 5$, 6-desaturation. FEBS Lett. 1997, 400, 80-82. [CrossRef]

67. Posch, W.; Blatzer, M.; Wilflingseder, D.; Lass-Flörl, C. Aspergillus terreus: Novel lessons learned on amphotericin B resistance. Med. Mycol. 2018, 56, S73-S82. [CrossRef] [PubMed]

68. Blum, G.; Perkhofer, S.; Haas, H.; Schrettl, M.; Würzner, R.; Dierich, M.P.; Lass-Flörl, C. Potential basis for amphotericin B resistance in Aspergillus terreus. Antimicrob. Agents Chemother. 2008, 52, 1553-1555. [CrossRef]

69. Andrews, F.A.; Sarosi, G.A.; Beggs, W.H. Enhancement of amphotericin B activity by a series of compounds related to phenolic antioxidants. J. Antimicrob. Chemother. 1979, 5, 173-177. [CrossRef]

70. Blatzer, M.; Jukic, E.; Posch, W.; Schöpf, B.; Binder, U.; Steger, M.; Blum, G.; Hackl, H.; Gnaiger, E.; Lass-Flörl, C. Amphotericin B resistance in Aspergillus terreus is overpowered by coapplication of pro-oxidants. Antioxid. Redox Signal. 2015, 23, 1424-1438. [CrossRef]

71. Shapiro, R.S.; Robbins, N.; Cowen, L.E. Regulatory circuitry governing fungal development, drug resistance, and disease. Microbiol. Mol. Biol. Rev. 2011, 75, 213-267. [CrossRef]

72. Cowen, L.E.; Lindquist, S. Hsp90 potentiates the rapid evolution of new traits: Drug resistance in diverse fungi. Science 2005, 309, 2185-2189. [CrossRef]

73. De Aguiar Cordeiro, R.; de Jesus Evangelista, A.J.; Serpa, R.; de Farias Marques, F.J.; de Melo, C.V.S.; de Oliveira, J.S.; da Silva Franco, J.; de Alencar, L.P.; Bandeira, T.d.J.P.G.; Brilhante, R.S.N. Inhibition of heat-shock protein 90 enhances the susceptibility to antifungals and reduces the virulence of Cryptococcus neoformans/Cryptococcus gattii species complex. Microbiology 2016, 162, 309-317. [CrossRef]

74. LaFayette, S.L.; Collins, C.; Zaas, A.K.; Schell, W.A.; Betancourt-Quiroz, M.; Gunatilaka, A.L.; Perfect, J.R.; Cowen, L.E. PKC signaling regulates drug resistance of the fungal pathogen Candida albicans via circuitry comprised of Mkc1, calcineurin, and Hsp90. PLoS Pathog. 2010, 6, e1001069. [CrossRef]

75. Blatzer, M.; Blum, G.; Jukic, E.; Posch, W.; Gruber, P.; Nagl, M.; Binder, U.; Maurer, E.; Sarg, B.; Lindner, H.; et al. Blocking Hsp70 Enhances the Efficiency of Amphotericin B Treatment against Resistant Aspergillus terreus Strains. Antimicrob. Agents Chemother. 2015, 59, 3778-3788. [CrossRef] [PubMed]

76. Seo, K.; Akiyoshi, H.; Ohnishi, Y. Alteration of cell wall composition leads to amphotericin B resistance in Aspergillus flavus. Microbiol. Immunol. 1999, 43, 1017-1025. [CrossRef] [PubMed]

77. Mesa-Arango, A.C.; Rueda, C.; Román, E.; Quintin, J.; Terrón, M.C.; Luque, D.; Netea, M.G.; Pla, J.; Zaragoza, O. Cell wall changes in amphotericin B-resistant strains from Candida tropicalis and relationship with the immune responses elicited by the host. Antimicrob. Agents Chemother. 2016, 60, 2326-2335. [CrossRef] [PubMed]

78. Casadevall, A.; Pirofski, L.-A. The damage-response framework of microbial pathogenesis. Nat. Rev. Microbiol. 2003, 1, 17-24. [CrossRef]

79. O'Keeffe, J.; Kavanagh, K. Adriamycin alters the expression of drug efflux pumps and confers amphotericin B tolerance in Candida albicans. Anticancer Res. 2004, 24, 405-408.

80. Niimi, M.; Niimi, K.; Takano, Y.; Holmes, A.R.; Fischer, F.J.; Uehara, Y.; Cannon, R.D. Regulated overexpression of CDR1 in Candida albicans confers multidrug resistance. J. Antimicrob. Chemother. 2004, 54, 999-1006. [CrossRef]

81. Chow, N.A.; Muñoz, J.F.; Gade, L.; Berkow, E.; Li, X.; Welsh, R.M.; Forsberg, K.; Lockhart, S.R.; Adam, R.; Alanio, A.; et al. Tracing the evolutionary history and global expansion of Candida auris using population genomic analyses. mBio 2020. [CrossRef]

82. Lockhart, S.R.; Etienne, K.A.; Vallabhaneni, S.; Farooqi, J.; Chowdhary, A.; Govender, N.P.; Colombo, A.L.; Calvo, B.; Cuomo, C.A.; Desjardins, C.A.; et al. Simultaneous emergence of multidrug-resistant Candida auris on 3 continents confirmed by whole-genome sequencing and epidemiological analyses. Clin. Infect. Dis. 2017, 64, 134-140. [CrossRef] 
83. Kean, R.; Ramage, G. Combined antifungal resistance and biofilm tolerance: The global threat of Candida auris. mSphere 2019, 4, e00458-19. [CrossRef]

84. Muñoz, J.F.; Gade, L.; Chow, N.A.; Loparev, V.N.; Juieng, P.; Berkow, E.L.; Farrer, R.A.; Litvintseva, A.P.; Cuomo, C.A. Genomic insights into multidrug-resistance, mating and virulence in Candida auris and related emerging species. Nat. Commun. 2018, 9, 5346. [CrossRef]

85. Woods, K.; Hofken, T. The zinc cluster proteins Upc2 and Ecm 22 promote filamentation in Saccharomyces cerevisiae by sterol biosynthesis-dependent and -independent pathways. Mol. Microbiol. 2016, 99, 512-527. [CrossRef] [PubMed]

86. Carolus, H.; Pierson, S.; Muñoz, J.F.; Subotić, A.; Cruz, R.B.; Cuomo, C.A.; Van Dijck, P. Genome-wide analysis of experimentally evolved Candida auris reveals multiple novel mechanisms of multidrug-resistance. bioRxiv 2020. [CrossRef]

87. Majka, J.; Burgers, P.M. Yeast Rad17/Mec3/Ddc1: A sliding clamp for the DNA damage checkpoint. Proc. Natl. Acad. Sci. USA 2003, 100, 2249-2254. [CrossRef] [PubMed]

88. Chowdhary, A.; Prakash, A.; Sharma, C.; Kordalewska, M.; Kumar, A.; Sarma, S.; Tarai, B.; Singh, A.; Upadhyaya, G.; Upadhyay, S.; et al. A multicentre study of antifungal susceptibility patterns among 350 Candida auris isolates (2009-17) in India: Role of the ERG11 and FKS1 genes in azole and echinocandin resistance. J. Antimicrob. Chemother. 2018, 73, 891-899. [CrossRef] [PubMed]

89. O’Brien, B.; Liang, J.; Chaturvedi, S.; Jacobs, J.; Chaturvedi, V. Pan-resistant Candida auris: New York Sub-cluster Susceptible to Antifungal Combinations. bioRxiv 2020. [CrossRef]

90. Arikan, S.; Lozano-Chiu, M.; Paetznick, V.; Nangia, S.; Rex, J.H. Microdilution Susceptibility Testing of Amphotericin B, Itraconazole, and Voriconazole against clinical Isolates of Aspergillus and Fusarium species. J. Clin. Microbiol. 1999, 37, 3946-3951. [CrossRef]

91. Anaissie, E.J.; Hachem, R.; Legrand, C.; Legenne, P.; Nelson, P.; Bodey, G.P. Lack of activity of amphotericin B in systemic murine fusarial infection. J. Infect. Dis. 1992, 165, 1155-1157. [CrossRef]

92. Al-Hatmi, A.; Curfs-Breuker, I.; De Hoog, G.S.; Meis, J.F.; Verweij, P.E. Antifungal susceptibility testing of Fusarium: A practical approach. J. Fungi 2017, 3, 19. [CrossRef]

93. Goldman, C.; Akiyama, M.J.; Torres, J.; Louie, E.; Meehan, S.A. Scedosporium apiospermum infections and the role of combination antifungal therapy and GM-CSF: A case report and review of the literature. Med. Mycol. Case Rep. 2016, 11, 40-43. [CrossRef]

94. Lamaris, G.A.; Chamilos, G.; Lewis, R.E.; Safdar, A.; Raad, I.I.; Kontoyiannis, D.P. Scedosporium infection in a tertiary care cancer center: A review of 25 cases from 1989-2006. Clin. Infect. Dis. 2006, 43, 1580-1584. [CrossRef]

95. Howden, B.; Slavin, M.; Schwarer, A.; Mijch, A. Successful control of disseminated Scedosporium prolificans infection with a combination of voriconazole and terbinafine. Eur. J. Clin. Microbiol. Infect. Dis. 2003, 22, 111-113. [CrossRef] [PubMed]

96. Cuenca-Estrella, M.; Ruiz-Díez, B.; Martínez-Suárez, J.V.; Monzón, A.; Rodríguez-Tudela, J.L. Comparative in vitro activity of voriconazole (UK-109,496) and six other antifungal agents against clinical isolates of Scedosporium prolificans and Scedosporium apiospermum. J. Antimicrob. Chemother. 1999, 43, 149-151. [CrossRef] [PubMed]

97. Sharma, C.; Chowdhary, A. Molecular bases of antifungal resistance in filamentous fungi. Int. J. Antimicrob. Agents 2017, 50, 607-616. [CrossRef] [PubMed]

98. Chaabane, F.; Graf, A.; Jequier, L.; Coste, A.T. Review on antifungal resistance mechanisms in the emerging pathogen Candida auris. Front. Microbiol. 2019, 10, 2788. [CrossRef]

99. Shin, J.H.; Kim, M.-N.; Jang, S.J.; Ju, M.Y.; Kim, S.H.; Shin, M.G.; Suh, S.P.; Ryang, D.W. Detection of amphotericin B resistance in Candida haemulonii and closely related species by use of the Etest, Vitek-2 yeast susceptibility system, and CLSI and EUCAST broth microdilution methods. J. Clin. Microbiol. 2012, 50, 1852-1855. [CrossRef]

100. Yang, Y.-L.; Li, S.-Y.; Cheng, H.-H.; Lo, H.-J. The trend of susceptibilities to amphotericin B and fluconazole of Candida species from 1999 to 2002 in Taiwan. BMC Infect. Dis. 2005, 5, 99. [CrossRef]

101. Ostrosky-Zeichner, L.; Rex, J.H.; Pappas, P.G.; Hamill, R.J.; Larsen, R.A.; Horowitz, H.W.; Powderly, W.G.; Hyslop, N.; Kauffman, C.A.; Cleary, J. Antifungal susceptibility survey of 2,000 bloodstream Candida isolates in the United States. Antimicrob. Agents Chemother. 2003, 47, 3149-3154. [CrossRef]

102. Ellis, D. Amphotericin B: Spectrum and resistance. J. Antimicrob. Chemother. 2002, 49, 7-10. [CrossRef] 
103. Gomez-Lopez, A.; Cuenca-Estrella, M.; Monzon, A.; Rodriguez-Tudela, J. In vitro susceptibility of clinical isolates of Zygomycota to amphotericin B, flucytosine, itraconazole and voriconazole. J. Antimicrob. Chemother. 2001, 48, 919-921. [CrossRef]

104. Almyroudis, N.G.; Sutton, D.A.; Fothergill, A.W.; Rinaldi, M.G.; Kusne, S. In vitro susceptibilities of 217 clinical isolates of zygomycetes to conventional and new antifungal agents. Antimicrob. Agents Chemother. 2007, 51, 2587-2590. [CrossRef]

105. Maraki, S.; Mavromanolaki, V.E.; Stafylaki, D.; Nioti, E.; Hamilos, G.; Kasimati, A. Epidemiology and antifungal susceptibility patterns of Candida isolates from Greek women with vulvovaginal candidiasis. Mycoses 2019, 62, 692-697. [CrossRef] [PubMed]

106. Badiee, P.; Alborzi, A. Susceptibility of clinical Candida species isolates to antifungal agents by E-test, Southern Iran: A five year study. Iran. J. Microbiol. 2011, 3, 183-188. [PubMed]

107. Bourgeois, N.; Dehandschoewercker, L.; Bertout, S.; Bousquet, P.-J.; Rispail, P.; Lachaud, L. Antifungal susceptibility of 205 Candida spp. isolated primarily during invasive candidiasis and comparison of the Vitek 2 system with the CLSI broth microdilution and Etest methods. J. Clin. Microbiol. 2010, 48, 154-161. [CrossRef] [PubMed]

108. Iatta, R.; Caggiano, G.; Cuna, T.; Montagna, T. Antifungal susceptibility testing of a 10-year collection of Candida spp. isolated from patients with candidemia. J. Chemother. 2011, 23, 92-96. [CrossRef] [PubMed]

109. Jung, S.-I.; Shin, J.H.; Choi, H.-J.; Ju, M.-Y.; Kim, S.-H.; Lee, W.G.; Park, Y.-J.; Lee, K. Antifungal susceptibility to amphotericin B, fluconazole, voriconazole, and flucytosine in Candida bloodstream isolates from 15 tertiary hospitals in Korea. Ann. Lab. Med. 2012, 32, 426-428. [CrossRef] [PubMed]

110. Lockhart, S.R.; Iqbal, N.; Cleveland, A.A.; Farley, M.M.; Harrison, L.H.; Bolden, C.B.; Baughman, W.; Stein, B.; Hollick, R.; Park, B.J. Species identification and antifungal susceptibility testing of Candida bloodstream isolates from population-based surveillance studies in two US cities from 2008 to 2011. J. Clin. Microbiol. 2012, 50, 3435-3442. [CrossRef]

111. Tsega, A.; Mekonnen, F. Prevalence, risk factors and antifungal susceptibility pattern of Candida species among pregnant women at Debre Markos Referral Hospital, Northwest Ethiopia. BMC Pregnancy Childbirth 2019, 19, 1-8. [CrossRef]

112. Yang, Y.-L.; Wang, A.-H.; Wang, C.-W.; Cheng, W.-T.; Li, S.-Y.; Lo, H.-J. Susceptibilities to amphotericin B and fluconazole of Candida species in Taiwan Surveillance of Antimicrobial Resistance of Yeasts 2006. Diagn. Microbiol. Infect. Dis. 2008, 61, 175-180. [CrossRef]

113. Christenson, J.C.; Guruswamy, A.; Mukwaya, G.; Retting, P.J. Candida lusitaniae: An emerging human pathogen. Pediatr. Infect. Dis. J. 1987, 6, 755-757. [CrossRef]

114. Hawkins, J.L.; Baddour, L.M. Candida lusitaniae infections in the era of fluconazole availability. Clin. Infect. Dis. 2003, 36, e14-e18. [CrossRef]

115. Krcmery, V.; Barnes, A. Non-albicans Candida spp. causing fungaemia: Pathogenicity and antifungal resistance. J. Hosp. Infect. 2002, 50, 243-260. [CrossRef] [PubMed]

116. Khan, Z.; Ahmad, S.; Al-Sweih, N.; Khan, S.; Joseph, L. Candida lusitaniae in Kuwait: Prevalence, antifungal susceptibility and role in neonatal fungemia. PLoS ONE 2019, 14, e0213532. [CrossRef] [PubMed]

117. Minari, A.; Hachem, R.; Raad, I. Candida lusitaniae: A cause of breakthrough fungemia in cancer patients. Clin. Infect. Dis. 2001, 32, 186-190. [CrossRef] [PubMed]

118. Pfaller, M.; Diekema, D.; Messer, S.; Boyken, L.; Hollis, R.; Jones, R. In vitro activities of voriconazole, posaconazole, and four licensed systemic antifungal agents against Candida species infrequently isolated from blood. J. Clin. Microbiol. 2003, 41, 78-83. [CrossRef] [PubMed]

119. Lima, S.L.; Francisco, E.C.; de Almeida, J.N., Jr.; Santos, D.W.d.C.L.; Carlesse, F.; Queiroz-Telles, F.; Melo, A.S.d.A.; Colombo, A.L. Increasing Prevalence of Multidrug-Resistant Candida haemulonii Species Complex among All Yeast Cultures Collected by a Reference Laboratory over the Past 11 Years. J. Fungi 2020, 6, 110. [CrossRef]

120. Cendejas-Bueno, E.; Kolecka, A.; Alastruey-Izquierdo, A.; Theelen, B.; Groenewald, M.; Kostrzewa, M.; Cuenca-Estrella, M.; Gómez-López, A.; Boekhout, T. Reclassification of the Candida haemulonii complex as Candida haemulonii (C. haemulonii group I.), C. duobushaemulonii sp. nov.(C. haemulonii group II), and C. haemulonii var. vulnera var. nov.: Three multiresistant human pathogenic yeasts. J. Clin. Microbiol. 2012, 50, 3641-3651. [CrossRef] 
121. De Almeida, J.N., Jr.; Assy, J.G.P.L.; Levin, A.S.; Del Negro, G.M.; Giudice, M.C.; Tringoni, M.P.; Thomaz, D.Y.; Motta, A.L.; Abdala, E.; Pierroti, L.C. Candida haemulonii complex species, Brazil, January 2010-March 2015. Emerg. Infect. Dis. 2016, 22, 561. [CrossRef]

122. Hou, X.; Xiao, M.; Chen, S.C.-A.; Wang, H.; Cheng, J.-W.; Chen, X.-X.; Xu, Z.-P.; Fan, X.; Kong, F.; Xu, Y.-C. Identification and antifungal susceptibility profiles of Candida haemulonii species complex clinical isolates from a multicenter study in China. J. Clin. Microbiol. 2016, 54, 2676-2680. [CrossRef]

123. Lockhart, S.R. Candida auris and multidrug resistance: Defining the new normal. Fungal Genet. Biol. 2019, 131, 103243. [CrossRef]

124. Pfaller, M.; Diekema, D.; Gibbs, D.; Newell, V.; Meis, J.; Gould, I.; Fu, W.; Colombo, A.; Rodriguez-Noriega, E. Results from the ARTEMIS DISK Global Antifungal Surveillance study, 1997 to 2005: An 8.5-year analysis of susceptibilities of Candida species and other yeast species to fluconazole and voriconazole determined by CLSI standardized disk diffusion testing. J. Clin. Microbiol. 2007, 45, 1735-1745. [CrossRef]

125. Wang, H.; Xiao, M.; Chen, S.C.; Kong, F.; Sun, Z.-Y.; Liao, K.; Lu, J.; Shao, H.-F.; Yan, Y.; Fan, H. Results from the National China Hospital Invasive Fungal Surveillance Net (CHIF-NET) Study, 2010: Yeast species and in vitro susceptibilities to fluconazole and voriconazole. J. Clin. Microbiol. 2012. [CrossRef] [PubMed] 
126. Arechavala, A.I.; Ochiuzzi, M.E.; Borgnia, M.D.; Santiso, G.M. Fluconazole and amphotericin B susceptibility testing of Cryptococcus neoformans: Results of minimal inhibitory concentrations against 265 isolates from HIV-positive patients before and after two or more months of antifungal therapy. Rev. Iberoam. Micol. 2009, 26, 194-197. [CrossRef] [PubMed]

127. Brandt, M.E.; Pfaller, M.A.; Hajjeh, R.A.; Hamill, R.J.; Pappas, P.G.; Reingold, A.L.; Rimland, D.; Warnock, D.W. Trends in antifungal drug susceptibility of Cryptococcus neoformans isolates in the United States: 1992 to 1994 and 1996 to 1998. Antimicrob. Agents Chemother. 2001, 45, 3065-3069. [CrossRef] [PubMed]

128. Chandenier, J.; Adou-Bryn, K.; Douchet, C.; Sar, B.; Kombila, M.; Swinne, D.; Therizol-Ferly, M.; Buisson, Y.; Richard-Lenoble, D. In vitro activity of amphotericin B, fluconazole and voriconazole against 162 Cryptococcus neoformans isolates from Africa and Cambodia. Eur. J. Clin. Microbiol. Infect. Dis. 2004, 23, 506-508. [CrossRef]

129. Espinel-Ingroff, A.; Aller, A.; Canton, E.; Castañón-Olivares, L.; Chowdhary, A.; Cordoba, S.; Cuenca-Estrella, M.; Fothergill, A.; Fuller, J.; Govender, N. Cryptococcus neoformans-Cryptococcus gattii species complex: An international study of wild-type susceptibility endpoint distributions and epidemiological cutoff values for fluconazole, itraconazole, posaconazole, and voriconazole. Antimicrob. Agents Chemother. 2012, 56, 5898-5906. [CrossRef]

130. Hagen, F.; Hare Jensen, R.; Meis, J.F.; Arendrup, M.C. Molecular epidemiology and in vitro antifungal susceptibility testing of 108 clinical Cryptococcus neoformans sensu lato and Cryptococcus gattii sensu lato isolates from Denmark. Mycoses 2016, 59, 576-584. [CrossRef]

131. Lei, Y.; Xiao, Y.; He, C.; Zhang, C.; Xie, Y.; Kang, M. Genotypes and in vitro antifungal susceptibility of Cryptococcus isolates in Sichuan Province. Sichuan Da Xue Xue Bao Yi Xue Ban J. Sichuan Univ. Med. Sci. Ed. 2015, 46, 82-86.

132. Perkins, A.; Gomez-Lopez, A.; Mellado, E.; Rodriguez-Tudela, J.L.; Cuenca-Estrella, M. Rates of antifungal resistance among Spanish clinical isolates of Cryptococcus neoformans var. neoformans. J. Antimicrob. Chemother. 2005, 56, 1144-1147. [CrossRef]

133. Gomez-Lopez, A.; Zaragoza, O.; Martins, M.D.A.; Melhem, M.; Rodriguez-Tudela, J.; Cuenca-Estrella, M. In vitro susceptibility of Cryptococcus gattii clinical isolates. Clin. Microbiol. Infect. 2008, 14,727-730. [CrossRef]

134. Francisco, E.; de Almeida, J.N., Jr.; de Queiroz Telles, F.; Aquino, V.; Mendes, A.; de Andrade Barberino, M.; Castro, P.d.T.O.; Guimarães, T.; Hahn, R.; Padovan, A. Species distribution and antifungal susceptibility of 358 Trichosporon clinical isolates collected in 24 medical centres. Clin. Microbiol. Infect. 2019, 25, 909.e1-909.e5. [CrossRef]

135. Guo, L.-N.; Yu, S.-Y.; Hsueh, P.-R.; Al-Hatmi, A.M.; Meis, J.F.; Hagen, F.; Xiao, M.; Wang, H.; Barresi, C.; Zhou, M.-L. Invasive infections due to Trichosporon: Species distribution, genotyping, and antifungal susceptibilities from a multicenter study in China. J. Clin. Microbiol. 2019, 57, e01505-18.

136. Taj-Aldeen, S.J.; Al-Ansari, N.; El Shafei, S.; Meis, J.F.; Curfs-Breuker, I.; Theelen, B.; Boekhout, T. Molecular identification and susceptibility of Trichosporon species isolated from clinical specimens in Qatar: Isolation of Trichosporon dohaense Taj-Aldeen, Meis \& Boekhout sp. nov. J. Clin. Microbiol. 2009, 47, 1791-1799. [PubMed]

137. Rodriguez-Tudela, J.L.; Diaz-Guerra, T.M.; Mellado, E.; Cano, V.; Tapia, C.; Perkins, A.; Gomez-Lopez, A.; Rodero, L.; Cuenca-Estrella, M. Susceptibility patterns and molecular identification of Trichosporon species. Antimicrob. Agents Chemother. 2005, 49, 4026-4034. [CrossRef] [PubMed]

138. Arabatzis, M.; Abel, P.; Kanellopoulou, M.; Adamou, D.; Alexandrou-Athanasoulis, H.; Stathi, A.; Platsouka, E.; Milioni, A.; Pangalis, A.; Velegraki, A. Sequence-based identification, genotyping and EUCAST antifungal susceptibilities of Trichosporon clinical isolates from Greece. Clin. Microbiol. Infect. 2014, 20, 777-783. [CrossRef] [PubMed]

139. Montoya, A.M.; Sánchez González, A.; Palma-Nicolás, J.P.; Gómez-Treviño, A.; González, J.G.; González, G.M. Genotyping, extracellular compounds, and antifungal susceptibility testing of Trichosporon asahii isolated from Mexican patients. Med. Mycol. 2015, 53, 505-511. [CrossRef]

140. Chagas-Neto, T.C.; Chaves, G.M.; Melo, A.S.; Colombo, A.L. Bloodstream infections due to Trichosporon spp.: Species distribution, Trichosporon asahii genotypes determined on the basis of ribosomal DNA intergenic spacer 1 sequencing, and antifungal susceptibility testing. J. Clin. Microbiol. 2009, 47, 1074-1081. [CrossRef]

141. Ribeiro, M.A.; Alastruey-Izquierdo, A.; Gomez-Lopez, A.; Rodriguez-Tudela, J.L.; Cuenca-Estrella, M. Molecular identification and susceptibility testing of Trichosporon isolates from a Brazilian hospital. Rev. Iberoam Micol. 2008, 25, 221-225. 
142. Borman, A.M.; Muller, J.; Walsh-Quantick, J.; Szekely, A.; Patterson, Z.; Palmer, M.D.; Fraser, M.; Johnson, E.M. MIC distributions for amphotericin B, fluconazole, itraconazole, voriconazole, flucytosine and anidulafungin and 35 uncommon pathogenic yeast species from the UK determined using the CLSI broth microdilution method. J. Antimicrob. Chemother. 2020, 75, 1194-1205. [CrossRef]

143. Messer, S.A.; Jones, R.N.; Fritsche, T.R. International surveillance of Candida spp. and Aspergillus spp.: Report from the SENTRY Antimicrobial Surveillance Program (2003). J. Clin. Microbiol. 2006, 44, 1782-1787. [CrossRef]

144. Reichert-Lima, F.; Lyra, L.; Pontes, L.; Moretti, M.L.; Pham, C.D.; Lockhart, S.R.; Schreiber, A.Z. Surveillance for azoles resistance in Aspergillus spp. highlights a high number of amphotericin B-resistant isolates. Mycoses 2018, 61, 360-365. [CrossRef]

145. Van Der Linden, J.W.; Warris, A.; Verweij, P.E. Aspergillus species intrinsically resistant to antifungal agents. Med. Mycol. 2011, 49, S82-S89. [CrossRef] [PubMed]

146. Ashu, E.E.; Korfanty, G.A.; Samarasinghe, H.; Pum, N.; You, M.; Yamamura, D.; Xu, J. Widespread amphotericin B-resistant strains of Aspergillus fumigatus in Hamilton, Canada. Infect. Drug Resist. 2018, 11, 1549. [CrossRef] [PubMed]

147. Chadeganipour, M.; Mohammadi, R. A 9-Year Experience of Aspergillus Infections from Isfahan, Iran. Infect. Drug Resist. 2020, 13, 2301. [CrossRef] [PubMed]

148. Koss, T.; Bagheri, B.; Zeana, C.; Romagnoli, M.F.; Grossman, M.E. Amphotericin B-resistant Aspergillus flavus infection successfully treated with caspofungin, a novel antifungal agent. J. Am. Acad. Dermatol. 2002, 46, 945-947. [CrossRef] [PubMed]

149. Alcazar-Fuoli, L.; Mellado, E.; Alastruey-Izquierdo, A.; Cuenca-Estrella, M.; Rodriguez-Tudela, J.L. Aspergillus section Fumigati: Antifungal susceptibility patterns and sequence-based identification. Antimicrob. Agents Chemother. 2008, 52, 1244-1251. [CrossRef] [PubMed]

150. Manikandan, P.; Abdel-Hadi, A.; Randhir Babu Singh, Y.; Revathi, R.; Anita, R.; Banawas, S.; Bin Dukhyil, A.A.; Alshehri, B.; Shobana, C.S.; Panneer Selvam, K. Fungal keratitis: Epidemiology, rapid detection, and antifungal susceptibilities of Fusarium and Aspergillus isolates from corneal scrapings. BioMed Res. Int. 2019, 2019, 6395840. [CrossRef] [PubMed]

151. Baddley, J.W.; Marr, K.A.; Andes, D.R.; Walsh, T.J.; Kauffman, C.A.; Kontoyiannis, D.P.; Ito, J.I.; Balajee, S.A.; Pappas, P.G.; Moser, S.A. Patterns of susceptibility of Aspergillus isolates recovered from patients enrolled in the Transplant-Associated Infection Surveillance Network. J. Clin. Microbiol. 2009, 47, 3271-3275. [CrossRef]

152. Husain, S.; Muñoz, P.; Forrest, G.; Alexander, B.D.; Somani, J.; Brennan, K.; Wagener, M.M.; Singh, N. Infections due to Scedosporium apiospermum and Scedosporium prolificans in transplant recipients: Clinical characteristics and impact of antifungal agent therapy on outcome. Clin. Infect. Dis. 2005, 40, 89-99. [CrossRef]

153. Steinbach, W.; Perfect, J. Scedosporium species infections and treatments. J. Chemother. 2003, 15, 16-27. [CrossRef]

154. Dalle Rosa, P.; Sheid, K.; Locatelli, C.; Marinho, D.; Goldani, L. Fusarium solani keratitis: Role of antifungal susceptibility testing and identification to the species level for proper management. Braz. J. Infect. Dis. 2019, 23, 197-199. [CrossRef]

155. Dallé da Rosa, P.; Ramirez-Castrillon, M.; Borges, R.; Aquino, V.; Fuentefria, A.M.; Goldani, L.Z. Epidemiological aspects and characterization of the resistance profile of Fusarium spp. in patients with invasive fusariosis. J. Med. Microbiol. 2019, 68, 1489-1496. [CrossRef] [PubMed]

156. Miceli, M.H.; Lee, S.A. Emerging moulds: Epidemiological trends and antifungal resistance. Mycoses 2011, 54, e666-e678. [CrossRef] [PubMed]

157. McGinnis, M.; Nordoff, N.; Li, R.-K.; Pasarell, L.; Warnock, D. Sporothrix schenckii sensitivity to voriconazole, itraconazole and amphotericin B. Med. Mycol. 2001, 39, 369-371. [CrossRef] [PubMed]

158. Kohler, L.M.; Soares, B.M.; de Assis Santos, D.; Da Silva Barros, M.E.; Hamdan, J.S. In vitro susceptibility of isolates of Sporothrix schenckii to amphotericin B, itraconazole, and terbinafine: Comparison of yeast and mycelial forms. Can. J. Microbiol. 2006, 52, 843-847. [CrossRef] [PubMed]

159. Trilles, L.; Fernández-Torres, B.; dos Santos Lazéra, M.; Wanke, B.; de Oliveira Schubach, A.; de Almeida Paes, R.; Inza, I.; Guarro, J. In vitro antifungal susceptibilities of Sporothrix schenckii in two growth phases. Antimicrob. Agents Chemother. 2005, 49, 3952-3954. [CrossRef] [PubMed]

160. Mahmoudi, S.; Zaini, F.; Kordbacheh, P.; Safara, M.; Heidari, M. Sporothrix schenckii complex in Iran: Molecular identification and antifungal susceptibility. Sabouraudia 2016, 54, 593-599. [CrossRef] [PubMed] 
161. Andreu, C.; León, A.; Medina, Y.; Machín, G.; Lancha, M.; Zaragozi, M. In vitro sensitivity of Histoplasma capsulatum var. capsulatum to amphotericin B, ketoconazole, itroconazole and fluconazole. Rev. Cuba. Med. Trop. 2003, 55, 76 .

162. Li, R.K.; Ciblak, M.A.; Nordoff, N.; Pasarell, L.; Warnock, D.W.; McGinnis, M.R. In vitro activities of voriconazole, itraconazole, and amphotericin B against Blastomyces dermatitidis, Coccidioides immitis, and Histoplasma capsulatum. Antimicrob. Agents Chemother. 2000, 44, 1734-1736. [CrossRef]

163. Wagner, L.; de Hoog, S.; Alastruey-Izquierdo, A.; Voigt, K.; Kurzai, O.; Walther, G. A revised species concept for opportunistic Mucor species reveals species-specific antifungal susceptibility profiles. Antimicrob. Agents Chemother. 2019, 63, e00653-19. [CrossRef]

164. Riley, T.T.; Muzny, C.A.; Swiatlo, E.; Legendre, D.P. Breaking the mold: A review of mucormycosis and current pharmacological treatment options. Ann. Pharmacother. 2016, 50, 747-757. [CrossRef]

165. Drogari-Apiranthitou, M.; Mantopoulou, F.-D.; Skiada, A.; Kanioura, L.; Grammatikou, M.; Vrioni, G.; Mitroussia-Ziouva, A.; Tsakris, A.; Petrikkos, G. In vitro antifungal susceptibility of filamentous fungi causing rare infections: Synergy testing of amphotericin B, posaconazole and anidulafungin in pairs. J. Antimicrob. Chemother. 2012, 67, 1937-1940. [CrossRef] [PubMed]

166. Alastruey-Izquierdo, A.; Castelli, M.; Cuesta, I.; Zaragoza, O.; Monzón, A.; Mellado, E.; Rodríguez-Tudela, J. In vitro activity of antifungals against Zygomycetes. Clin. Microbiol. Infect. 2009, 15, 71-76. [CrossRef] [PubMed]

167. Vitale, R.G.; de Hoog, G.S.; Schwarz, P.; Dannaoui, E.; Deng, S.; Machouart, M.; Voigt, K.; van de Sande, W.W.; Dolatabadi, S.; Meis, J.F. Antifungal susceptibility and phylogeny of opportunistic members of the order mucorales. J. Clin. Microbiol. 2012, 50, 66-75. [CrossRef] [PubMed]

168. Park, B.J.; Arthington-Skaggs, B.A.; Hajjeh, R.A.; Iqbal, N.; Ciblak, M.A.; Lee-Yang, W.; Hairston, M.D.; Phelan, M.; Plikaytis, B.D.; Sofair, A.N.; et al. Evaluation of Amphotericin B Interpretive Breakpoints for Candida Bloodstream Isolates by Correlation with Therapeutic Outcome. Antimicrob. Agents Chemother. 2006, 50, 1287-1292. [CrossRef]

169. Rex, J.H.; Pfaller, M.A.; Barry, A.L.; Nelson, P.W.; Webb, C.D. Antifungal susceptibility testing of isolates from a randomized, multicenter trial of fluconazole versus amphotericin B as treatment of nonneutropenic patients with candidemia. NIAID Mycoses Study Group and the Candidemia Study Group. Antimicrob. Agents Chemother. 1995, 39, 40-44. [CrossRef]

170. Nguyen, M.H.; Clancy, C.J.; Yu, V.L.; Yu, Y.C.; Morris, A.J.; Snydman, D.R.; Sutton, D.A.; Rinaldi, M.G. Do In Vitro Susceptibility Data Predict the Microbiologic Response to Amphotericin B? Results of a Prospective Study of Patients with Candida Fungemia. J. Infect. Dis. 1998, 177, 425-430. [CrossRef]

171. Clancy, C.J.; Nguyen, M.H. Correlation between In Vitro Susceptibility Determined by E Test and Response to Therapy with Amphotericin B: Results from a Multicenter Prospective Study of Candidemia. Antimicrob. Agents Chemother. 1999, 43, 1289-1290. [CrossRef]

Publisher's Note: MDPI stays neutral with regard to jurisdictional claims in published maps and institutional affiliations.

(C) 2020 by the authors. Licensee MDPI, Basel, Switzerland. This article is an open access article distributed under the terms and conditions of the Creative Commons Attribution (CC BY) license (http://creativecommons.org/licenses/by/4.0/). 